\title{
金属の防食規程，防食基準ならびに関連規格について
}

\author{
福 谷 英 二* \\ *中川防蝕工業株式会社
}

\section{The Regulations, Standards and Related Specifications for Corrosion Control}

Eiji Fukutani*

*Nakagawa Corrosion Protecting Co.

\begin{abstract}
Some abstracts of the regulations, standards and related specifications for corrosion control mainly in Japan are described. Some important examples of the foreign reqgulations, standards and specifications for corrosion control are also summerized.
\end{abstract}

\section{1. まえがき}

防食問題は資源の節約掞よび経済上重要な問題である が，経済問題が深くかかわるだけに，法令によって強制 されることは一般に行なわれていない。しかし石油関係 の貯蔵施設，輸送パイプラインなどは腐食穿孔による漏 油がある場合に，火災や爆発の怙それがあるので，法規 によって防食を義務ずけられている国が多い。

防食の基準，それに関連する資材や工法の規格は，極 力制定に努められているが，基準化や規格化のためには データの蓄積と多くの人の合意が必要であるために，古 くから用いられている材料や工法などが主として基準 化，規格化されており，新規なすぐれた材料や工法など はまだ決定を見ない状沉にあることは止むを得ないとこ ろである。基準と規格の分類は必ずしも明確でないが， 工法に類するものは主として基準に，材料に属するもの は主として規格に入れた。

規程，基準，規格などを漏れなく述べることは至難で あるが，筆者が調查した範囲で必要と考光たものについ てまとめて見た。腐食に関係のある試験規格, 分析規格, 金属材料規格，電線規格などについては特に必要と認め たもの以外は割愛した。

\section{2. 規 程}

\section{1 国内規 程}

石油の貯蔵タンク，輸送パイプラタンなどは腐食穿孔 のための漏油によって災害の源となるので，法規によっ て防食措置を強制されている。

* 干101 東京都千代田区神田鍛治町 2-2-2 (2-2-2, Kanda Kaji-cho, Chiyoda-ku, Tokyo 101, Japan)

\subsection{1 パイプラインの防食}

石油パイプライン事業の事業用施設の技術上の基準を 定める省令（昭和 47 年 12 月 25 日号外, 通商産業省, 運輸省，建設省，自治省令第 2 号)

第 9 条 地下または海底に設置する導管等は, 告示で 定めるところにより, 而久性があり, かつ, 電気絶縁抵 抗の大きい塗覆装材料により外面腐食を防止するための 措置を施さなければならない。

第 10 条 地下または海底に設置する導管等には，告 示で定めるところにより電気防食措置を講じなければな らない。

な特この省令の細目を定める告示が昭和 48 年 9 月 28 日，通商産業省，運輸省，建設省，自治省告示第 1 号に 定められている。

\subsection{2 貯蔵タンクの防食}

危険物の規制酒関する政令（昭和 34 年 9 月 26 日政 令第 306 号） [昭和 50 年 7 月 8 日政令第 215 号（消防 法施行令の一部を改正する政令附則 3 項による改正) ]

(1) 屋外貯蔵タンク

第 11 条七 屋外貯蔵タンクの外面には, さび止めの ための塗装をすること。

(2) 屋内貯蔵タンク

第 12 条六 屋内貯蔵タンクの外面には，さび止めの ための塗装をすること。

(3) 地下タンクの貯藏所

第 13 条七 地下タンクの外面には，さび止めのため の塗装をすること。

(4) 簡易貯藏所

第 14 条七 簡易貯蔵タンクの外面には, さび止めの 
ための塗装をすること。

(5) 移動タンク貯蔵所

第 15 条入 移動貯蔵タシクの外面には, さび止めの ための塗装をすること。

(6) タンク底板外面の防食措置

第 21 条の 2 屋外貯蔵タンクの底板の外面の腐食を 防止するための措置は次に揭げるいずれかによるるのと する。

一、タンク底板の下に, タンク底板の腐食を有効に防 止できるようにアスファルトサンド等の防食材料を敷く こと。

二、タンク底板に電気防食の措置を講ずること

三、前各号に揭げるもの之同等以上の底板の腐食を防 止することができる措置を講ずること

（7）地下タンク外面の保護の方法

第 24 条一 タンクの外面にさび止め拉よびアスファ ルトプライマーの順に塗装を行なった後, アスファルト ルーフィングおよびワイヤーラスの順にタンクを被覆 し，その表面に厚さ $2 \mathrm{~cm}$ 以上に達するまでモルタルを 塗装すること。

\subsection{3 排水基準}

水質污染により人畜，魚類などに危害を生じないため 水質基準が定められている。これを表 1 亿示す。腐食抑 制剂とか表面処理の排水を河海に流す際には，この基準 を守らなければならない。

人の健康にかかる環境基準（昭和 46 年 12 月 28 日 環境庁告示)

表 1 排水中の有害物質許容量

\begin{tabular}{|c|c|}
\hline 品名 & 含 有 量 (ppm) \\
\hline シアン & \\
\hline アルキル水銀 & \\
\hline 総，水 銀 & 柍出されふいこと \\
\hline 有機りん & \\
\hline カドミウム & $<0.01$ \\
\hline 6 価クロム & $<0.05$ \\
\hline 鉛 & $<0.1$ \\
\hline
\end{tabular}

\section{2 国外規 程}

国外規程としてパイプラインに対するアメリカ連邦規 程を取上げた。

Federal Register, Vol. 36, 126, June 30 (1970) (49 CER-Part, 192-Substruct 1) 192, 455

（1） 192，461 の諸要件に適合する防食塗装を施すこ $\varepsilon_{0}$

（2） パイプライン設置後， 1 年以内に，本規定に従 って，パイプライン全体を防食できるように設計した電 気防食法を講じ，これを稼動しなければならない。

\section{3. 基 準}

\section{1 塗装と被覆}

\subsection{1 国内基準}

3.1.1.1 一 般

構造物の塗装と被覆に関しては, 一般に, 施設所有者 が自からの仕様書を作製して，これによって施行させる ことが多いので，公式に基準化したものは少ない。わが 国で塗装, 被覆の基準と考号られているものには次のよ らなものがある。

JASS-18 塗装工事：日本建築学会建築工事標準仕様 書。

JRS 5000, 3689, 19 AR 3 (1964) 日本国有鉄道仕様 書：鉄けたの塗装方法。

JRS 1963 日本国有鉄道工作局：車輛用塗料抢よび塗 装関係規格。

JIS D 0201 自動車部品の電気めっき通則。

JIS D 0202 自動車部品の塗膜通則。

JIS W 2014 航空機々体および機体部品の塗装なら びに防護被覆。

JISW 2007 航空機々体拈よび機体部品の 金属表面処 理。

SR 139 部会資料 No, 184, 200, 221 (造船研究協会): 塗装前鋼材表面処理基準（写真判定）

JIS H 9124 溶融亜鉛めっき作業標準

JIS H 9126 溶融アルミニウムめっき作業標準。

JIS H 9300 亜鉛溶射作業標準

JIS H 9301 アルミニウム溶射作業標準

JIS H 8651 マグネシウム合金防食処理方法

JIS H 9500 アルミニウム打よびアルミニウム合金の 硫酸陽極酸化処理技術基準

JIS H 9501 アルミニウム抢よびアルミニウム合金の しゅ5酸陽極酸化処理技術基準

JIS H 8602 アルミニウム拈よびアルミニウム合金の 陽極酸化塗装

JIS Z 0301 防湿包装方法

JIS Z 0302 防水包装

JIS Z 0303 さび止め包装方法通則

3.1.1.2 埋 設 管

埋設管の塗覆装は瀝青質で行うものは次の基準によ る。ポリエチレン被覆とかテープ巻きの基準はない。

JIS G 3491 水道用鋼管アスファルト塗装方法

JIS G 3492 水道用鋼管コールタールエナメル叙覆装 方法

\subsection{2 国 外基準}

3.1.2.1 一 般

(1) 前 処 理

a. SSPC-63 (Steel Structure Painting Council 
塗装前処理として次のように定めている。

SSPC-SP 1-63 溶剂清浄

SSPC-SP 2-63 手工具清浄

SSPC-SP 3-63 動力工具清浄

SSPC-SP 4-63 火焰清浄

SSPC-SP 5-63 ホワイトメタルブラスト清浄

SSPC-SP 6-63 商業用ブラスト清浄

SSPC-SP 7-63 ブラシオフブラスト清浄

SSPC-SP 8-63 酸洗い清浄

SSPC-SP 9-63T 暴露後ブラスト清浄

SSPC-SP 10-63T ニヤホワイトメタルブラスト清浄 最低の前処理基準としては，油性系叙料に対しては SP2 で良いが，他の塗料に対してはSP6か SP8 を奖め ている。

b. SIS 055900-1967 スェーデン規格

写真判定の前処理基準を定めている。SSPC との関係 は次に示すようである。

$\begin{array}{lll}\text { SIS } & \text { Sa } 1 & \text { SSPC-SP7-63 } \\ \text { SIS } & \text { Sa } 2 & \text { SSPC-SP 6-63 } \\ \text { SIS } & \text { Sa } 2 \frac{1}{2} & \text { SSPC-SP 10-63T } \\ \text { SIS } & \text { Sa } 3 & \text { SSPC-SP 5-63 }\end{array}$

c. NACE 基準

NACE RP-01-72 [訳：防食技術, 22, No. 6 (1973)] 水ブラスト法による鋼材その他の表面処理

\section{d. NACE 準基準}

Pub. 53-1 (TP-6G) 塗装前の鋼材前処理

T6F-2 (1963) 鋼およびュンクリート表面の前処理

T6G (1974) 遠心式ブラスト法

T6G (1976) 遠心式ブラスト法

(2) 塗装と被覆

a. NACE 基準

NACE RP-03-72 [訳：防食技術， 22, No. 4 (1973)]

貢貸用生産タンクのコールタールェポキシによるライ ニング方法

NACE RP-03-76 床コンクリートの 1 回塗りサーフ エーサーの特性, 施行法, 保守法

NACE RP-01-78 薬液用金属性タンクおよび容器の 設計, 組立ならびに表面仕上法

b. NACE 準基準

Pub. 57-7 (TIM) 海洋環境での塗装

Pub. 57-8 (TM-2) 海洋環境でのコールタールエナ メル塗装

Pbu. 57-10 (T6B) 大気中の塗装系の前処理，塗装掠 よび耐久性

Pub. 61-1 (T6D) 防食塗装の前処理と材料の選択

Pub. 61-2 (T6E) 石油生産施設の塗装

Pub. 61-8 (T6D-4) 工場内前処理ならびにプライマ
一塗装

T-1G-2 (1963) 油井管のセメントライニング法

T-6B-10 (1963) 大気中構造物のビニル塗装

T-6B-17 (1963) 大気中構造物のコールタール塗装

T1H-1 (1963) タンク内面ライニング法

T6A-21 (1966)＼cjkstart塩化ポリェーテル塗装ならびにライ ニング

T6H-26 (1977) 大気中構造物のビニル塗装

c. イギリス基準 CP 2008 (1966)

“鉄鋼構造物の腐食防止法”

大気暴露構造物の初期塗装計画を表 2 亿示す。

表 2 大気暴露構造物の初期塗装計画

$$
\text { A 塗装区分 }
$$

\begin{tabular}{|c|c|c|c|c|}
\hline 処 & 理 & \multirow[b]{2}{*}{ 塗 } & \multirow[b]{2}{*}{ 装 } & \multirow[b]{2}{*}{ 系 } \\
\hline $\begin{array}{l}\text { 金属被覆または } \\
\text { 前 } \quad \text { 处 理 }\end{array}$ & 前 処 理 & & & \\
\hline $\begin{array}{l}\text { 溶融めっき } \\
\text { 溶射亜鉛 } \\
\text { 溶射アルミニウム }\end{array}$ & $\begin{array}{l}\text { エッチング } \\
\text { プライマー }\end{array}$ & \multicolumn{3}{|c|}{ 耐薬品性塗装系 } \\
\hline ブラスト清浄 & $\begin{array}{l}\text { エッチング } \\
\text { プライマー }\end{array}$ & \multicolumn{3}{|c|}{ 瀝青質塗装（厚膜，冷間） } \\
\hline $\begin{array}{l}\text { 酸洗い } \\
\text { 火焰清浄 } \\
\text { 手加工清浄 }\end{array}$ & & $\begin{array}{l}\text { さびとめ } \\
\text { プライマ }\end{array}$ & \multicolumn{2}{|c|}{$\begin{array}{l}\text { MIO系油性上塗り, } \\
\text { 長油アルキッド系 } \\
\text { あるいは油性上塗 }\end{array}$} \\
\hline
\end{tabular}

\section{B 等 級}

\begin{tabular}{|c|c|c|c|}
\hline \multirow{2}{*}{$\begin{array}{l}\text { 等 } \\
\text { 級 } \\
\end{array}$} & \multirow{2}{*}{ 表 面処 理 } & \multicolumn{2}{|r|}{ 装系 } \\
\hline & & プライマー & 上 \\
\hline 1 & 金属被覆 & $\begin{array}{l}\text { エッチング } \\
\text { プライマー }\end{array}$ & $\begin{array}{l}\text { 耐薬品性または㴪青質 } \\
\text { 塗裴 }\end{array}$ \\
\hline 2 & 金属被覆 & $\begin{array}{l}\text { エッチング } \\
\text { プライマー }\end{array}$ & $\begin{array}{l}3 \sim 4 \text { 回塗り (環境と金 } \\
\text { 属被覆により塗料選定) }\end{array}$ \\
\hline 3 & $\begin{array}{l}\text { ブラストある } \\
\text { いは炎焰清浄 }\end{array}$ & & $\begin{array}{l}\text { 耐薬品性または溾青質 } \\
\text { 塗裴 }\end{array}$ \\
\hline 4 & 同上 & $\begin{array}{l}\text { さびとめプラ } \\
\text { イマー2 回 }\end{array}$ & 上塗 2 回 \\
\hline 5 & 手工具清浄 & 同上 & 上 \\
\hline 6 & 同上 & $\begin{array}{l}\text { さびとめプラ } \\
\text { イマー1 回 }\end{array}$ & 同 \\
\hline$M$ & 裸金属塗装 & & \\
\hline
\end{tabular}

\section{C 推奖等級}

\begin{tabular}{|c|c|c|c|c|c|c|}
\hline \multirow{2}{*}{ No. } & \multirow{2}{*}{ 構 造 物 } & \multicolumn{3}{|c|}{ 環 } & \multicolumn{2}{|l|}{ 境 } \\
\hline & & 田 園 & 工 業 & 重工業 & 海 岸 & 海 洋 \\
\hline 1 & $\begin{array}{c}\text { 屋外重要構造物 } \\
(\text { 例：橋梁) }\end{array}$ & \begin{tabular}{|l}
$\mathrm{M}, 4$ \\
または2
\end{tabular} & 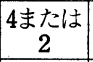 & 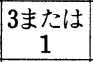 & $\begin{array}{c}4 \text { 4たは } \\
2\end{array}$ & $\begin{array}{c}3 \text { 3まは } \\
1\end{array}$ \\
\hline 2 & $\begin{array}{l}\text { 屋外その他の構 } \\
\text { 造物 }\end{array}$ & \begin{tabular}{|l}
$\mathrm{M}, 5$ \\
または
\end{tabular} & \begin{tabular}{|l|}
$\mathrm{M}, 4$ \\
または2
\end{tabular} & 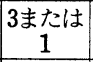 & 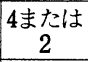 & $\begin{array}{c}3 \text { 3または } \\
1\end{array}$ \\
\hline 3 & 屋内構造物 & $\begin{array}{l}\text { Mまた } \\
\text { は6 }\end{array}$ & \begin{tabular}{|l|}
$\begin{array}{l}\text { Mまた } \\
\text { は6 }\end{array}$ \\
\end{tabular} & \begin{tabular}{|c|}
3 または \\
1
\end{tabular} & $\begin{array}{l}\mathrm{M} \text { また } \\
\text { は } 6\end{array}$ & - \\
\hline
\end{tabular}

表 3 には代表的塗装系を示した。 
表 3 . 代表的塗装系

A 記号の説明

\begin{tabular}{|c|c|c|c|c|c|}
\hline 項 目 & 記号 & 容 & 項 目 & 記号 & 容 \\
\hline 表 面 & $\begin{array}{l}\mathrm{A} \\
\mathrm{B}\end{array}$ & $\begin{array}{l}\text { ブラスト } \\
\text { 酸洗い }\end{array}$ & \multirow{4}{*}{$\begin{array}{l}\text { 油性系 } \\
\text { 塗 料 }\end{array}$} & $\mathrm{L}$ & MIO入り塗料 \\
\hline 処 理 & $\mathrm{C}$ & 火焰清浄 & & $\mathrm{S}$ & 長油アルキッド \\
\hline & D & 手工具清浄 & & $\mathrm{T}$ & \multirow{2}{*}{$\begin{array}{l}\text { 油性系 (BS - } \\
2525-32)\end{array}$} \\
\hline \multirow{2}{*}{$\begin{array}{l}\text { 金 属 } \\
\text { 被 覆 }\end{array}$} & $E$ & 溶融覀鉛めっき & & 1 & \\
\hline & $\mathrm{F}$ & $\begin{array}{l}\text { 溶射亜鉛, 溶射 } \\
\text { アルミニウム }\end{array}$ & $\begin{array}{l}\text { 瀝青系 } \\
\text { 塗 料 }\end{array}$ & $\mathrm{N}$ & $\begin{array}{l}\text { 瀝青系塗料 } \\
\text { (厚膜，冷間) }\end{array}$ \\
\hline 前処理 & G & エッチプライマー & \multirow{3}{*}{$\begin{array}{l}\text { 酎薬品 } \\
\text { 性塗料 }\end{array}$} & $\mathrm{P}$ & $1 ;$ \\
\hline \multirow{2}{*}{$\begin{array}{l}\text { さびと } \\
\text { めプラ } \\
\text { イママ }\end{array}$} & $\mathrm{H}$ & 鉛丹プライマー & & $\mathrm{Q}$ & 塩化ゴム \\
\hline & $\begin{array}{l}\mathrm{J} \\
\mathrm{K}\end{array}$ & $\begin{array}{l}\text { 鉛酸カルシウム } \\
\text { ジシククロメート }\end{array}$ & & $\mathrm{R}$ & $\begin{array}{l}\text { コールタール } \\
\text { エポキシ }\end{array}$ \\
\hline
\end{tabular}

B 代表的塗装系

\begin{tabular}{|c|c|c|}
\hline 環 境。 & 塗装方法 & 記 \\
\hline 海洋地带 & AまたはB & 瀝青系塗料にはCCでも可 \\
\hline $\begin{array}{l}\text { 化学的環 } \\
\text { 境 }\end{array}$ & $\begin{array}{lll}\mathrm{N}, & \mathrm{P}, & \mathrm{Q} \\
\text { または } & \mathrm{R} \\
\end{array}$ & $\begin{array}{l}\text { 膜厚は } 5 \mathrm{mils} \text { 以上, 塗り回数は } 2 \\
\text { 回以上 }\end{array}$ \\
\hline \multirow{3}{*}{ 同上 } & EまたはF & \\
\hline & $1 \quad G$ & \\
\hline & $\begin{array}{lll}\mathrm{N}, & \mathrm{P}, & \mathrm{Q} \\
\text { または } & \mathrm{R} \\
\end{array}$ & $\begin{array}{l}\text { 膜厚は } 5 \mathrm{mils} \text { 以上, 塗り回数は } 2 \\
\text { 回以. }\end{array}$ \\
\hline \multirow{3}{*}{$\begin{array}{c}\text { 海岸地带 } \\
\text { Class } 1 \\
\& 2\end{array}$} & AまたはB & \\
\hline & $2 \mathrm{H}$ & \\
\hline & $2 \mathrm{~L}$ & Class2には 2S の代用も可 \\
\hline \multirow{3}{*}{ 同上 } & $\mathrm{F}$ & \\
\hline & \begin{tabular}{|c|c|c|}
$1 \mathrm{~J}$ & $1 \mathrm{G}+$ & $1 \mathrm{G}+$ \\
$1 \mathrm{~K}$ & $2 \mathrm{~K}$ \\
\end{tabular} & \\
\hline & \begin{tabular}{|l|l|l|}
$2 \mathrm{~L}$ & $2 \mathrm{~L}$ & $2 \mathrm{~L}$ \\
\end{tabular} & $\begin{array}{l}\text { Class2には2Lの代りに， Eの上に } \\
\text { は1L+1S，Fの上には2S 年可 }\end{array}$ \\
\hline 工業地帯 & $\mathrm{A}, \mathrm{B}$ ВたはC & \\
\hline \multirow{2}{*}{$\begin{array}{l}\text { 田園地带 } \\
\text { Class } 1 \\
\end{array}$} & $2 \mathrm{H}$ たは2J & 田園地帯には $2 \mathrm{~K}$ も可 \\
\hline & $2 \mathrm{~L}$ & \\
\hline \multirow{2}{*}{$\begin{array}{l}\text { 工業地帯 } \\
\text { 田園地帯 }\end{array}$} & A, BまたはC & 田園地帯ではDも可 \\
\hline & \begin{tabular}{l|l|}
$2 \mathrm{H}$ & $2 \mathrm{~J}$ \\
\end{tabular} & 田園地帯では $2 \mathrm{~K}$ も可 \\
\hline Class 2 & \begin{tabular}{|l|c|}
$2 \mathrm{~L}, 2 \mathrm{~S}$ & $2 \mathrm{~L}$ \\
または & または \\
$2 \mathrm{~T}$ & $\mathrm{LL}+1 \mathrm{~S}$ \\
\end{tabular} & \\
\hline 工業地帯 & $\mathrm{D}$ & 工業地带にはBまたはCが望ましい \\
\hline \multirow{2}{*}{$\begin{array}{l}\text { 田園地带 } \\
\text { Class } 3\end{array}$} & \begin{tabular}{|l|l|}
$1 \mathrm{H}$ & $1 \mathrm{~J}$ \\
\end{tabular} & 田園地带には $1 \mathrm{~K}$ も可 \\
\hline & \begin{tabular}{|c|c|}
$2 \mathrm{~L}, 2 \mathrm{~S}$ & $2 \mathrm{~L}$ \\
または & または \\
$2 \mathrm{~T}$ & $1 \mathrm{~L}+1 \mathrm{~S}$ \\
\end{tabular} & \\
\hline
\end{tabular}

備考： $2 \mathrm{H}$ などの数字は塗り回数を示す。

\subsubsection{2 埋 設 管}

(1) NACE RP-01-69 [訳：防食技術，19，No. 8 (1970)]

“地下および水中の金属配管系の外面腐食の制御”に塗 覆装基準を次のように挙げている。

AWWA 8310-D (AWWA-C203) アメリカ水道管用 コールタール防食被覆系の標準
NACE 2G 156 地下埋設管用コールタール防食被覆 NACE 2H 257 地下埋設管用アフスァルトマスチッ 》防食被覆

NACE 2H 157 地下埋設管用アスファルト系防食塗 覆装

NACE 2H 158 地下埋設管用アスファルト系防食被 覆

NACE 2L 161 地下埋設管用加熱溶融ワックス系防 食塗覆装

NACE 2K 161 管路防食用成形プラスチックフィル ム

(2) NACE 基準

NACE RP-02-74 管路被覆の埋設前の高電圧電気試 験法

NACE RP-02-75 [訳：防食技術, 24, No. 11 (1975)] 埋設管の外面有機系塗装の適用法

NACE RP-03-75 埋設管用ワックス型塗覆装法

NACE RP-02-76 埋設管用引抜アスファルトマスチ ック型塗装法

\section{2 陰極防食}

\subsection{1 国内基準}

(1) 防食電位基準

防食電位基準は，石油パイプライン事業の事業施設の 基準を定める省令 (昭和 48 年 9 月 28 日号外, 通商産 業省, 運輸省, 建設省, 自治省令第 1 号) に規定されて いる。

第 21 条一, 地下または海底に設置する導管等の対地 電位平均值は, 飽和硫酸銅電極基準による場合にあって は $-0.85 \mathrm{~V}$, 飽和カロメル電極基準による場合にあって は $-0.77 \mathrm{~V}$ 上り負の電位であって, から, 過防食によ る悪影響を生じない範囲内とする。

これが国内で定められた唯一の公的基準であるが，こ れは他の環境に招いても一般的に防食基準電位と考光ら れている。

(2) 電気防食施設基準

通商産業省公益事業局制定の “電気設備の技術基準” 第 5 章第 4 節第 248 条に電気防食施設の安全のための電 圧規定その他が定められている。その要点を次に述べ る。

a. 防食回路の最高二次電圧は直流 $60 \mathrm{~V}$ とする。

b. 陽極は地中に埋設し, あるいは水中の人が容易に 触れる括それがない場所に施設すること。

c. 地中に埋設する陽極 (バックフィルのある場合は これを含む) の埋設の深さは $75 \mathrm{~cm}$ 以上であること。

d. 水中に施設する陽極とその周圈 $1 \mathrm{~m}$ 以内の距離に

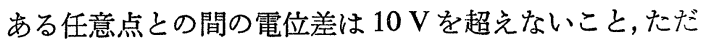
乙陽極の周囲に人が触れるのを防止するために適当なさ 
くを設け,かつ,危険表示をする場合はとの限りでない。

e. 地表または水中に特ける $1 \mathrm{~m}$ の間隔を有する任意 の 2 点(前号の陽極の周囲 $1 \mathrm{~m}$ 以内の距離にある点およ

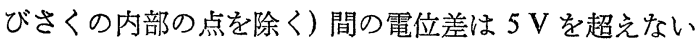
こと。

(3) 電食防止の施設基準

通商産業省公益事業局制定の “電気設備の技術基準” 第 6 章第 2 節に直流慢線関係, 排流接続関係など, 電気 鉄道側の排流施設に対する基準が定められている。

(4) その他

a. JIS A 4201 避雷針の接地法

厚さ $1.4 \mathrm{~mm}$ 以上, 面積片面 $0.35 \mathrm{~m}^{2}$ の銅板, 厚さ 3 $\mathrm{mm}$ 以上, 面積片面 $0.35 \mathrm{~m}^{2}$ 以上の溶融亜鉛めっき鋼板 またはこれと同等以上の棒状，管状，帯状，板状，うず まき状の金属体。

アルミニウムその他これに類する腐食しやすいものは 使用してはならない。

接地抵抗は $10 \Omega$ 以下とする（各引火導線の接地抵抗 は $20 \Omega$ 以下とする)。

b. JIS C 0903 一般用電気機器の防爆構造通則

\section{2 国外基 準}

主として陰極防食電位基準について述べる。

3.2.1 NACE RP-01-69 〔訳：防食技術，19, No. 8 (1970)]

“地下括よび水中金属配管系の外面腐食の制御”の中に 陰極防食電位基準が定められている。この基準は Federal Register, Vol. 36 の連邦規程および NACE RP-06-75 “海中鋼管の腐食制御”中の基準と全く同じである。

(1) 鉄鋼構造物

a. 通電状態のまま計測して，管対地電位は飽和硫酸 銅電極基準で $-0.85 \mathrm{~V}$ より卑であること

b. 通電状態のまま計測して, 陰極の電位変化が卑の 方向に $300 \mathrm{mV}$ 以上であること

c. 電流を遮断した直後に計測して, 陰極の電位変化 が卑の方向に $100 \mathrm{mV}$ 以上であること

(2) アルミニウム構造物

a. 通電状態のまま計測したアルミニウム院極の電位 変化が卑の方向に $150 \mathrm{mV}$ 以上であること

b. 電流を遮断した直後に計測して，陰極の電位変化 が卑の方向に $100 \mathrm{mV}$ 以上であること

c. 通電中計測したアルミニウム陰極の対地電位が, 飽和硫酸銅電極基準に対し $-1.2 \mathrm{~V}$ より卑にならないこ 之

（3）銅系構造物

電流遮断直後に計測した陰極の電位変化が卑の方向に $100 \mathrm{mV}$ 以上であること

（4）異種金属接触構造物
通電中の陰極電位が，不通電時の最も卑な部分の電位 よりも卑となること。

3.2.2 C.C.I.T.T “公衆電気通信用ケーブルの製造, 建 設および防護に関する勧告”

電話ケーブルの腐食, 被覆, 外装, 布設, 電気防食な ぞについて規定しているが，その中での防食電位基準を 表 4 に示した。

表 4 陰極防食電位基準 (飽和硫酸銅電極基準)

\begin{tabular}{|c|c|c|}
\hline 金 属 & 境 & 防食電位 (V) \\
\hline 鉛 & 地下埋設, 水中 & -0.55 \\
\hline 鉛 & 管路中 & -0.60 \\
\hline 鉄 鋼 & 地下埋設, 水中 & -0.85 \\
\hline 鉄 鋼 & 媻気性環境 & -0.95 \\
\hline 鉄 鋼 & 強アルカリ性 $(\mathrm{pH}>12)$ 環境 & -1.00 \\
\hline
\end{tabular}

註：鉛はー $2 \mathrm{~V} よ り$ 卑になれば㓌極腐食を生ずる。

\subsubsection{NACE RP-05-75 “油処理槽の内面陰極防法”}

電流遮断直後の電位を飽和硫酸銅電極基準で $-0.85 \mathrm{~V}$, 飽和カロメル電極基準で $-0.78 \mathrm{~V}$, 銀塩化銀 電極基準で $-0.81 \mathrm{~V}$ としている。 RP-01-69 の基準と は電解質中の IR 降下の差がある。

3.2.4 RP-01-76 [訳：防食技術, 26, No. 5 (1977)] “固定海中穿井プラットホームの腐食制御”では飽和銀, 塩化銀電極基準で $-0.8 \mathrm{~V}$ とてているこの值には海水 中の IR 降下は含まない。

3.2.5 イギリスの電気防食基準 CP 1021 (1973) (CP 2008 の電気防食基準もほぼ同じである)。

(1) 防食電位基準

表 5 に防食電位基準を示す。

表 5 イギリスの陰極防食電位基準 (CP 1021) (V)

\begin{tabular}{|c|c|c|c|c|c|}
\hline \multicolumn{2}{|c|}{ 材料 } & $\mathrm{Cu} / \mathrm{CuSO}_{4}$ & $\begin{array}{r}\mathrm{Ag} / \mathrm{AgCl} \\
/ \text { 海水 }\end{array}$ & $\begin{array}{c}\mathrm{Ag} / \mathrm{AgCl} \\
/ \text { 飽和 } \mathrm{KCl}\end{array}$ & $\mathrm{Zn} /$ 海水 \\
\hline \multirow{2}{*}{ 鋼 } & 好気性 & -0.85 & -0.8 & -0.75 & +0.25 \\
\hline & 嫌気性 & -0.95 & -0.9 & -0.85 & +0.15 \\
\hline \multicolumn{2}{|c|}{$\begin{array}{c}\text { 鉛 } \\
\text { 銅 系 合金 } \\
\text { アルミニウム }\end{array}$} & $\begin{array}{c}-0.6 \\
-0.5 \sim \\
-0.65 \\
-0.95 \sim \\
-1.2\end{array}$ & $\begin{array}{c}-0.55 \\
-0.45 \\
-0.60 \\
-0.9 \sim \\
-1.15\end{array}$ & $\begin{array}{c}-0.50 \\
-0.4 \sim \\
-0.55 \\
-0.85 \sim \\
-1.1\end{array}$ & $\begin{array}{c}+0.50 \\
+0.6 \sim \\
+0.45 \\
+0.35 \\
-0.10\end{array}$ \\
\hline
\end{tabular}

(2) そ の 他

a. 直流二次電圧は最高 $50 \mathrm{~V}$

b. 干渉による他施設の電位変化は $+20 \mathrm{mV}$ を限度 とする。

c. 塗覆装埋設管の最卑電位は飽和硫酸銅電極基準で $-2.5 \mathrm{~V}$ とする。

d. 水中に括ける塗装した施設の電位は油性系塗料で は $\mathrm{Ag} / \mathrm{AgCl} /$ 海水電極基準で $-0.8 \mathrm{~V}$ ，エポキシ，塩化ビ ニル，塩化ゴム系塗料で $-0.9 \mathrm{~V}$ より卑な電位としない 
こと

e. 陽極(バックフィルを含む)はは地表から $30 \mathrm{~cm}$ 上 り深く埋設すること

\subsection{6 その他の NACE 基準}

電気防食に関して次の NACE 基準がある。 NACE RP-05-72〔訳：防食技術, 22, No. 8 (1973)] 外部電源用深埋設電極の設計, 設置および保守法 NACE RP-01-74 地下埋設配電装置の腐食抑制 NACE RP-01-77 防食装置に対する交流抢よび落雷 の影響の軽減法

\subsubsection{NACE 準基準}

電気防食に関する NACE の準基準には次の上らなも のがある。

Pub. 60-7 (T3G-1) 船体外板の陰極防食 T10C-6 (1971) 地下埋設配電装置の腐食制御

\section{3 そ 他}

\subsection{1 国外基 準}

(1) NACE RP-01-70 [訳：防食技術，21，No. 5 (1972)] 石油精製装置休止中の中和剂使用飞よる腐食制 御

(2) NACE RP-02-72 〔訳：防食技術，22, No. 5 (1973)] 防食法の経済比較の計算方法

（3） NACE RP-04-72 腐食性の石油精製装置環境中 飞未新る炭素鋼 $(\mathrm{P}-1)$ の溶接部の使用中に起こる水素脆 性破壊の防止法。硬度を Brinell 200 以下にすれば良い。

(4) NACE RP-01-73 [訳：防食技術，23，No. 2 (1974)] 腐食生成物の試料の採集之同定

(5) NACE RP-02-73 抑制剤を添加した油田酸の取 扱いと適当な使用法

(6) NACE RP-01-75 [訳：防食技術，24, No. 11 (1975)]鋼管系の内面防食法, 水分, 酸, 腐食性ガスの 除去, 腐食抑制剤の添加, 内部の塗装, ライニングなど の基準を示している。

（7） NACE RP-04-75 含油地層への各種注入水の取 扱いに用いられる金属材料の選定法。

(8) NACE RP-07-75 油生産施設に括ける腐食試験 片の準備叔よび設置と試験成績の解釈。

\section{4. 規 格}

\section{1 塗装と被覆}

\subsection{1 国内規 格}

(1) 塗 料

塗料の規格を次汇示す。

JIS K 5411 油ワニス

JIS K 5421 ボイル油拈よび煮あまに油

JIS K $5431 \sim \mathrm{K} 5432$ ワニス系

JIS K 5491 トラフィックペイント
JIS K 5492 アルミニウムペイント

JIS K 5506 K 5512 調合ペイント系 JIS K 5531 K 5543 ラッカー系

JIS K 5562 フタル酸樹脂ワニス

JIS K 5571 プタル酸樹脂エナメル

JIS K $5581 \sim \mathrm{K} 5583$ 塩化ビニル樹脂系

JIS K 5591 K 5594 オイル系

JIS K 5612 K 5617 焼付塗料系

JIS K $5621 \sim \mathrm{K} 5628$ さび止め塗料系

JIS K 5631 鋼船外板用油性塗料

JIS K 5634 鋼船外板用塩化ビニル塗料

JIS K 5637 デッキペイント

JIS K 5638 鋼船外板用塩化ゴム系塗料

JIS K $5641 \sim \mathrm{K} 5648$ カシュー樹脂系

JIS K $5651 \sim \mathrm{K} 5652$ アミノアルキド樹脂系

JIS K 5661 建築用防火塗料

JIS K 5662 粉状水性塗料

JIS K 5663 合成樹脂エマルジョンペイント

JIS K 5664 タールエポキシ樹脂塗料

JIS K 5667 K 5668 模様塗料系

JIS K 5671 発光塗料

JIS K 5673 安全色彩用けい光塗料

JIS K 5851 ～K 5852 船舶用ビチューメン系

JIS K 5902 ロジン

JIS K 5903 エステルガム

(2) 覆装剤拉よび前処理剤

JIS A 5504 ワイヤーラス

JIS A 6004 アスファルトルーフィング

JIS L 3405 ヘッシァンクロス

JIS G 5903 鋳造用ショット打よびグリット

（3）金属被覆

JIS H 8300 亜鉛溶射

JIS H 8301 アルミニウム溶射

JIS H 8602 アルミニウム拈よびアルミニウム合金の

陽極酸化皮膜

. JIS H 8610 電気亜鉛めっき

JIS H 8611 カドミウムめっき

JIS H 8641 溶融刺鉛めっき

JIS H 8642 溶融アルミニウムめっき

(4) 包装関係

JIS Z 1503 Z 1540 紙，紙製品，テープ類

JIS Z 1704 熱間浸漬可はく性プラスチック

JIS Z 1705 さび止め用耐油性バリアー材

JIS Z 1708 塗装系可はく性プラスチック

JIS Z 1709 収縮包装用フィルム

JIS Z 1801 溶剂希釈形さび止め油

JIS Z 1802 Z 1806 さび止め油，グリース類 
JIS Z 1901 防食用ビニルテープ

\subsection{2 国外規 格}

(1) アメリカ軍の塗料規格

国内にアメリカ軍基地がある関係上 MIL-STD-171A (ord）は関心が持たれて招り，日本防錆技術協会が昭和 37 年 3 月に塗装関係の訳文を発表している。その中の 鋈料規格を次に示す。

MIL-C-15328A ウォッシュプライマー

MIL-C-5807B (ASG) 金属用ウォッシュプライマー TT-E-485d さび止め半つやエナメル

MIL-E-10687B 速乾性スチレンアルキド樹脂つや消 エナメル

MIL-L-1195B ラッカーつや消エナメル（ホットス プレー)

TT-P-636b エナメルプライマー

TT-P-664a 耐ラッカー性プライマー

TT-P-666a アルミニウム特よびマグネシウム表面 用ジンクロメートプライマー

TT-P-662-1 プライマーサーフェーサー（ラッカー およびェナメル用）

MIL-P-11414A ラッカープライマー（防せい用）

MIL-P-15930A ビニル樹脂ジンクロメートプライ マー

MIL-P-27316 (USAF) 航空機用熱反射エポキシ樹 脂プライマー

TT-E-527a-1 フタル酸樹脂つや消エナメル

MIL-E-74B 速乾性フタル酸樹脂つや消エナメル

MIL-P-12742 (CE)A フェノール樹脂プライマー(水 浸漬用を含む)

MIL-E-12507 (CE)A フェノール樹脂つや消エナメ ル (外部用)

TT-E-529a フタル酸樹脂半つやエナメル

JAN-E480 焼付フェノールまたは尿素ーフォルムア ルデヒド樹脂エナメル

MIL-L-52043 (ord) ニトロセルローズ半つやラッカ $-$

MIL-E-13515 (ord) さび止めビニルアルキド樹脂半 つやエナメル

TT-E-489C フタル酸樹脂つや有エナメル(内外部用) MIL-L-12277 (ord) 自動車用ホットスプレーラッカ

TT-V-51C アスファルトワニス

MIL-E-5558A 航空機用ちりめん模様エナメル MIL-P-13380 (ord) スポットウエルド用プライマー MIL-C-450A 溶哃型ビチュミナス黒ペイント TT-C-520-1 自動車用アンダーボデー用プライマー MIL-P-14458A 耐発煙硝酸性ゴム塗料
MIL-P-14276A (ord) 耐熱用けい素樹脂系シルバー ペイント

TT-A-580a 鉛白含有一般用漏出防止剂（ねじ部充眖 用）

MIL-S-11030B シーリングコンパウンド-非硬化性 MIL-S-7502C (ASG)-1 燃料タンク用シーリングコ ンパウンド

(2) NACE 準規格

Pub. 54-4 (T-6A) ポリビニル，クロールアセテート

Pub. 56-4 (T-6A) 硬質ポリビニル，クロライド

Pub. 56-5 (T-6A) エポキシ樹脂

Pub. 57-9 (T-6A-3) ビニリデンクロライド

Pub. 59-7 (T-6A-5) ポリエチレン

Pub. 60-16 (T6H) グラスライニングとビトリアスエ ナメル

Pub. 6 1-3 (T6A-18) クロルスルフォネートポリエ チレン

Pub. 61-7 (T6B-11) 無機亚鉛塗料

Pub. 61-13 (T6A-1) ゴムライニング

T6A-7 (1962) コールタール

T2J-3 (1962) 瀝青飽和のガラス覆装材

T6A-7 (1962) ウレタン塗装

T2J-2 (1962) ファイバーグラス覆装材

T2J-1 (1962) アスベストフェルト

T6A-4 (1962) フェノール樹脂

T6A-10 (1962) 不飽和酸含有ポリエステル樹脂

T6A-12 (1963) クローロカーボン樹脂

T6A-9 (1963) フルフリールアルコール樹脂塗料

T6A-6 (1963) ネオプレン樹脂塗料

T6A-1 (1964)，前処理用砥粒

T6B-5 (1965) アルキッド樹脂塗料

T6A-19 (1966) アスファルト

T6A-21 (1966) 塩化ポリエーテル塗料ならびにライ ニング

T6B (1967) フェノール樹脂塗料

T6B-8 (1970) アミン硬化エポキシ樹脂

T6H-9 (1975) 塩化ゴム

T6A-25 (1976) 浸漬部用無機覀鉛塗装

(3) その他のアメリカ軍規格

MIL-STD-171A (ord) 化成処理関係

MIL-STD-171A (ord) めつき関係

以上のものは日本防錆技術協会が昭和 37 年に訳文を 発表している。な拉アメリカ軍規格中次のものについて も日本防錆技術協会の訳文がある。

防錆油編（昭和 37 年訳); 防錆前処理編（昭和 38 年 訳); 防錆材料編 (昭和 45 年訳)

\section{2 電気防食その他}


表 6 防食用マグネシウム陽極の組成 (\%) (JS H-6125)

\begin{tabular}{|c|c|c|c|c|c|c|c|c|c|}
\hline 種 類 & $\mathrm{Al}$ & $\mathrm{Zn}$ & $\mathrm{Mn}$ & $\mathrm{Fe}$ & $\mathrm{Ni}$ & $\mathrm{Cu}$ & $\mathrm{Si}$ & $\mathrm{Mg}$ & 用 途 \\
\hline 一種 & 0.01 & -0.00 & $<0.01$ & 0.002 & $<0.001$ & 1 & 1 & 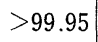 & \multirow{2}{*}{$\begin{array}{l}\text { 全 } \\
\text { 環 } \\
\text { 境 }\end{array}$} \\
\hline 二種 & $\begin{array}{r}5.3 \sim \\
6.7 \\
\end{array}$ & $\begin{array}{r}2.5 \sim \\
3.5 \\
\end{array}$ & $\begin{array}{r}0.15 \sim \\
0.60 \\
\end{array}$ & $<0.003$ & $<0.001$ & 2 & $<0$ & E & \\
\hline 第三種 & $\begin{array}{r}5.3 \sim \\
6.7\end{array}$ & $\begin{array}{r}2.5 \sim \\
3.5\end{array}$ & $\begin{array}{r}0.15 \sim \\
0.60\end{array}$ & $<$ & 3 & 5 & $<$ & 残 & 中 \\
\hline
\end{tabular}

\subsection{1 国内規格}

(1) 電気防食

電気防食用マグネシウム陽極の組成は JIS H 6125 K 定められている。これを表 6 亿示す。

(2) その他

a. ボイラー水

JIS B 8223 ボイラーの給水执よびボイラー水の水質

b. 熱交換器用黄銅管の使用基準 (石油学会)

JPI-7R-32-74（1974 年 2 月改訂）

冷却水の管内流速の限度を表 7 のごとく定めている。

表 7 冷却水の速度限度 $(\mathrm{m} / \mathrm{sec})$

\begin{tabular}{l|c|c}
\hline \hline 水 & BsTF 1 & BsTF 2 - 4 \\
\hline 淡 水 & 2.5 & 3.5 \\
一般海水 & 1.2 & 1.8 \\
有効鉄分を含む海水 & 1.5 & 2.5 \\
\hline
\end{tabular}

c. 主要な試験規格

Z 0304-74 さび止め処理金属の大気暴露試験

$\mathrm{Z}$ 2371-76 塩水噴霧試験方法

$\mathrm{Z} 8802$ 水素イオン濃度 $(\mathrm{pH})$ 测定方法

4.2.2 国外規格

（1）電気防食用亜鉛陽極の規格

a. ANSI/ASTM B418-73

表 8 亿 ASTM 規格を示す。

表 8 防食用亜鉛陽極の組成 $(\%)$ (ASTM B418-73)

\begin{tabular}{|c|c|c|c|c|}
\hline タイプ & $\mathrm{Al}$ & $\mathrm{Cd}$ & $\mathrm{Fe}$ & $\mathrm{Zn}$ \\
\hline 1 & $0.10 \sim 0.40$ & $0.03 \sim 0.10$ & $<0.005$ & Bal. \\
\hline 2 . & $<0.005$ & $<0.003$ & $<0.0014$ & Bal. \\
\hline
\end{tabular}

b. アメリカ軍規格

アメリカ軍規格を表 9 亿示す。

(2) NACE 電気防食準規格
Pub. 57-4 (T2B) 高けい素鋳鉄電極

Pub. 60-3 (T2B-4) 高けい素鋒鉄電極

(3) NACE 推奨の材料規格

NACE MR-01-74 サッカーロッド用としての腐食 抑制剂を添加した潤滑剤の選定

NACE MR-02-74 パイプライン被覆用の 4 種類の 合成樹脂の特性

NACE MR-01-75（1978 改正）油田装置用の硫化水 素亀裂に強い金属材料

NACE MR-01-76 硫化水素環境に強いサッカーロ ッドポンプ用金属材料

(4) NACE 推奨の試験規格

NACE TM-01-69 [訳：防蝕技術, 21, No. 1 (1972)] 装置工業に和ける金属の実験室腐食試験方法

NACE TM-01-71 [訳：防蝕技術, 21, No. 9(1972)] 高温水中に和ける金属腐食のオートクレーブ試験法

NACE TM-02-72 [訳：防蝕技術, 21, No. 10 (1972)] パイプラインによって輸送される石油製品の防食性能試 験法

NACE TM-01-73 漉膜を用いた表面下注射水の水 質決定試験法

NACE TM-01-74 浸漬用ライニング材として用い られる防食被覆の評価のための実験室試験

NACE TM-02-74 高温水中に特ける金属の動的試 験法

NACE TM-03-74 溶液中から硫酸カルシウム，炭酸 カルシウムの析出を防止するスケール抑制剤の能力決定 のための実験室選択試験法

NACE-02-75 サッカーロッドを直列につないで行 万性能試験法

NACE-03-75 落下砂試験機を用いての焼付け薄膜 およびライニング膜の摩耗試験法

NACE TM-01-77 室温での硫化水素応力腐食飞強 い金属の試験方法

表 9 防食用亜鉛陽極の組成 $(\%)$

\begin{tabular}{|c|c|c|c|c|c|c|c|}
\hline MIL-Ño. & $\mathrm{Al}$ & $\mathrm{Cd}$ & $\mathrm{Cu}$ & $\mathrm{Pb}$ & $\mathrm{Si}$ & $\mathrm{Fe}$ & $\mathrm{Zn}$ \\
\hline $18001 \mathrm{G}$ & $0.1 \sim 0.5$ & $0.025 \sim 0.15$ & $<0.005$ & $<0.006$ & 0.125 & $<0.005$ & Bal. \\
\hline $18001 \mathrm{~B}$ & $<0.1$ & $<0.004$ & $<0.005$ & $<0.006$ & - & $<0.0014$ & Bal. \\
\hline
\end{tabular}


(5) その他の NACE 準規格

Pub. 55-2 (TIK) 油井およびガス井用腐食抑制剂の 選定

Pub. 55-3 (T3A) 腐食抑制剂のリスト

Pbu. 57-12 (T3C-1) 冷却水腐食抑制剂の試験法
T8A (1962) 酸洗い用腐食抑制剂

T3A (1964) 自動車機関冷却水用腐食抑制剂

T1D (1967) 油井用腐食抑制剂

Pub. 55-7 (T-1J) 油井構造物用プラスチック

(1978 年 11 月 15 日受理) 